\title{
Krzysztof Kubiak
}

Jan Kochanowski University in Kielce

k.kubiak@ujk.edu.pl

ORCID: 0000-0002-9623-923X

\section{Portuguese Navy operations on Lake Niassa (1967-1974)}

Keywords: Mozambique, Lake Niassa, guerrilla war, counterguerrilla operations, Portuguese Navy

In 1964, the Mozambique Liberation Front (Frente de Libertação de Moçambique, FRELIMO), operating from Tanzania, commenced guerrilla warfare against the Portuguese. Fighting took place in the northern part of the border provinces - eastern Cabo Delgado and western Niassa, adjacent to the great lake bearing the same name. Due to climatic conditions and topography of the province of Niassa ${ }^{1}$, the lake was the most convenient route for the partisans to travel from the north to the south. In order to break the infiltration route, the Portuguese Navy (Armada Portuguesa) was forced to organise and maintain a group of units consisting of patrol and landing boats, as well as a special sub-subunit of marines. It was an absolutely unique undertaking in the history of maritime warfare ${ }^{2}$. It should be noted that for the Portuguese Navy the war in Mozambique began much earlier - on 24 September 1964; a group of a dozen or so partisans from FRELIMO fired upon Cobué on Lake Niassa, specifically targeting the local administration office located there (one of the five located in

1 Area 129 thousand $\mathrm{km}^{2}$, population in 1960 - 285,000 (farmer and farmer-gatherer population living in large family groups), average population density 2 people $/ \mathrm{km}^{2}$, belonging to the Macua, Nyanya and Yao tribal groups. The provincial administrative centre, Vila Cabral (now Lichinga) had about 3,000 residents. It is an upland area (altitudes range from 500 to $1600 \mathrm{~m}$ above sea level). In the dry season, rainfall drops to $15 \mathrm{~mm}$ per month, in the rainy season it is about $250 \mathrm{~mm}$ per month.

2 During the Great War, the theatre of the struggle was Lake Tanganyika, but any search for greater similarities between those events and the Portuguese activity on Lake Niassa is not justified. 
the Lago District, which stretches as a narrow strip along the shore, starting from the border with Tanzania).

\section{COMBAT OPERATIONS AREA - LAKE NIASSA}

Lake Niassa, also known as Malawi and Nyasa, is the southernmost of the Great African Lakes, which include - starting from the north: Lake Turkana (Rudolf), Lake Kyoga (Kioga), Lake Albert, Lake Edward, Lake Victoria, Lake Kivu, Lake Tanganyika, Lake Mweru, and the alkaline Lake Rukwa, all of them filling the tectonic depressions known as the East African Rift. It is a true inland sea, the fourth largest freshwater reservoir in the world (by volume) and the ninth largest lake in the world with a surface area of $29,600 \mathrm{~km} 2$ (almost the area of Belgium). The length of the lake is $580 \mathrm{~km}$, the greatest width is $75 \mathrm{~km}$, the maximum depth is $706 \mathrm{~m}$. The largest river flowing into Malawi is the Ruhuhu and the largest outlet is the River Shire (Shiré, Chire) which is, through Lake Malombe, a tributary of the Zambezi. The water temperature on the surface ranges from 24 to $29^{\circ} \mathrm{C}$. There are no tides and currents on the lake, but in strong winds, short storm waves can reach up to $2.5 \mathrm{~m}$. This is especially common between May and August, when the noon wind known as the mvera can turn into a squall. Moreover, navigation is hampered by seasonal changes in the water level up to $5 \mathrm{~m}$ (the highest level in May, the lowest in December) $)^{3}$.

The lake was discovered by Europeans relatively late. It was only in 1846 that the Portuguese merchant Candido José da Costa Cardoso managed to reach it, and after him, in 1859, came David Livingstone (who called it Lake of Storms). In 1954, a water delimitation was carried out between the Portuguese Mozambique and the British territories (Nyasaland and Tanganyika). The border ran through the middle of the lake, however, leaving the islands of Chizumulu (4.4 km long, greatest width $1.3 \mathrm{~km}$ ) and Likoma (7.1 km long, greatest width $2.0 \mathrm{~km}$ ) along with two smaller islands in British hands. These were therefore exclaves, initially British and later and now Malawian, in Mozambique waters. The larger island of Likoma is located $4.5 \mathrm{~km}$ from the Mozambique coast, $28 \mathrm{~km}$ from the border separating the waters of both countries and 60 $\mathrm{km}$ from the Malawi coast. For Chizumulu, these values are 20.5, 10.0 and $48.2 \mathrm{~km}$, respectively.

In the initial stage of the conflict, the Portuguese kept on the lake (mainly for prestige, not military reasons) the 20-ton hydrographic vessel Mina, transported in 1957 by train from Beira via Chipoka to Metangula, and a 22-ton patrol boat Castor, also

3 Paul F. Hamblin, Harwey A. Bootsma, Robert E. Hecky, “Surface Meteorological Observations over Lake Malawi/Nyasa”, Journal of Great Lakes Research 29 (2003), Supplement 2: 22. 
transported from the Indian Ocean (from Nacala via Catur and Meponda to Metangula) in December 1963. . From the end of 1962, marines from special forces (Destacamento de Fuzileiros Especiais № 2) were stationed at the lake - one platoon in Cobuè and another in Metangula. In 1963 in Metangula, the Command for the Defence of Lake Niassa and the Ports was organised (Comando da Defesa Marítima e da Capitania dos Portos do Lago Niassa).

Organising systematic counterguerrilla activities at the turn of 1964 and 1965, the Portuguese (a platoon of marines) intercepted combatants camping in the border region on 5 January 1965 (it is not clear on which side of the border it happened). They also determined that the enemy had developed two main infiltration routes ${ }^{6}$ :

- one running through the waters of the lake from towns (marinas) on its eastern shore (including settlements relatively well connected with Dar es Salaam, such as Mbamba located about $40 \mathrm{~km}$ from the border, or Liuli located approx. $35 \mathrm{~km}$ further north) directly to Mozambique,

- another leading from Tanzania, across Lake Niassa towards its north-eastern outskirts, and further south, taking advantage of the particular course of the border of Malawi, towards the Mozambique provinces of Tetè, Sofala and Zambezia (the province of Tetè being particularly threatened by infiltration).

To block them, additional vessels were required. In August 1965, a decision was made to transfer Antares and Regulus patrol boats from the coast of the Indian Ocean to Lake Niassa. Two more vessels - large flat-bottomed boats with a shallow draft were to be built on site: one in Lepoche on the Tanzanian border and the other in Cobué. However, this decision was quickly changed. Due to the escalation of the enemy's activity, it was decided to transfer two larger vessels to the lake (Marte and Mercúrio patrol boats), along with the previously planned Regulus patrol boat and an LDM 404 landing boat ${ }^{7}$.

4 In September 1963, the vessel was delivered from the home country to Nacala by the freighter Sofala. This liner had a very interesting history. It was an ex-German vessel Aller, originally owned by Bremen Norddeutscher Lloyd, which operated it on Far Eastern and Australian lines. After the outbreak of the war, it took refuge in Lourenço Marques. In May 1943, it was seized by the Portuguese and handed over to Companhia Nacional de Navegação. With a gross tonnage of 7,956, the ship built in 1937 at the Bremen Vulkan AG shipyard in Vegesack became one of the largest freighters flying the Lusitanian ensign. It remained in operation until 1968, then the vessel was scrapped in Spanish Castellon. Sofala, accessed: 13.01.2020, http://alernavios.blogspot.com/2016/07/sofala.html.

5 Pedro Lauret, A Marinha de Guerra Portuguesa. Do fim da II Gueraa Mundial ao 25 Abril de 1974 (Vila do Conde: Verso da História, 2015), 217.

6 John. P. Cann, Brown Waters of Africa. Portuguese Riverine Warfare 1961-1974 (Solihull: Helion \& Company Limited, 2016), 38.

7 Ibidem, 140. 


\section{TRANSPORT OF THE VESSELS TO LAKE NIASSA}

Regulus had a displacement of 18 tons, so it was smaller than the patrol boat Castor (22 tons) which had previously been transported to the lake; the landing boat's displacement was 19 tons. However, the patrol boats Marte and Mercurio displaced 32 tons each, which significantly complicated the entire project in terms of logistics and transport. The plan was to transport the vessels on railway flat wagons from Lumbo to Villa Cabral, and then on low-bed trailers to Meponda on Lake Niassa. While the railway stage did not seem to cause major problems, which turned out however to be a symptom of rather wishful thinking, the road phase raised serious concerns from the very beginning. First of all, they were related to the condition of the roads, which became impassable stripes of mud during the rainy season lasting from November to April. No information was available on the load-bearing capacity of bridges and necessary clearance under structural elements, as well as the strength of culverts. Moreover, with the limited amount of heavy equipment, most of the work had to be done using the simplest hand tools. The transport service did not have at its disposal either appropriate trailers or tractor units, but this could be solved in a relatively simple way by acquiring the appropriate equipment from South African companies providing services to the mining industry. At that time, the guerrillas began to plant mines on the roads between Cobuè, Metangula and Villa Cabral, which required the inclusion of sub-units of sappers from the ground force, who in turn required protection from the sub-units of riflemen. The entire operation, codenamed Atum (tuna), began to consume more and more resources. The distances planned to cover were as follows: from Lumbo to Nampula, by rail - $180 \mathrm{~km}$, from Napula to Villa Cabral by rail - about 750 $\mathrm{km}$, from Villa Cabral to Meponda by road - about $70 \mathrm{~km}^{8}$.

In August 1965, engineering reconnaissance began on the planned ship transport route. In this regard, the military closely collaborated with engineers assigned to assist them by the Mozambique Railways Directorate (Ferro de Moçambique). Already the first reconnaissance showed that on the route between Lumbo and Monapo, one bridge was too low for flat wagons with ships to pass under it without obstruction, while five others needed reinforcement. However, the alternative route from Nacala to Monapo required even more time and money. This situation required a thorough revision of the planned project, as it had initially been assumed that the operation would start in Nacala. After the adoption of the modified plan, the preparation of a special slipway at Lumbo was immediately started (which had to be adapted to the operation of railway stock, as it was planned to use it to mount the vessels on the flat wagons). It should be

8 Operação “Atum”. Transporte de Lanchas da Marinha do Lumbo a Meponda, accessed: 13.01.2020, https://niassa1558.blogspot.com/2019/02/operacao-atum-transporte-de-lanchas-da.html. 
noted that to this day there is no port or a larger marina there, and goods are delivered from the roadstead by lighters and barges. During that time, rigs (cradles) for the ships were to be brought from Nacala, while heavy tractor units capable of towing platforms were to arrive from Lourenço Marques. The work was very intensive and all the time under time pressure. In fact, calculations indicated that the highest tide, which could greatly facilitate the implementation of the first stage of the project, would occur on 13 and 14 September. However, the deadline was not met ${ }^{9}$.

In the first ten days of September, the freighter Beira (built in 1963, capacity 14,200, hull built by Arsenal do Alfeite, vessel completed in the Netherlands ${ }^{10}$ ) dropped anchor off the coast of the Island of Mozambique. Marte and Mercúrio were her deck cargo. On 9 September, both patrol boats were launched, but as the slipway had not yet been completed, the first of the ships was mounted on a railway wagon and pulled ashore only on 17 September. Fortunately, it turned out that the highest tide range was not necessary. However, there was another unexpected problem. Namely, the Mozambique Railways Directorate informed the Navy that it did not see the possibility of completing the entire project and was withdrawing from cooperation ${ }^{11}$. This was probably due to the fear that heavy flat wagons would cause damage to the track, for which the army would not be willing to pay later. For this reason, the ship was eventually launched again. At the end of September, the LDM 404 landing craft, towed by Pacheco Pereira frigate, arrived at the Mozambique Island. It did not require high water for loading and a kind of "dress rehearsal" was carried out with its use. On 29 September, the flat-bottomed vessel was mounted on a railway flat wagon without the use of joists. On 2 October, the transport reached Nampula and proceeded to Villa Cabral. One serious obstacle was encountered in the form of the bridge in Monapo, which proved too narrow for a landing boat to move between its arches. The Navy's carpenter, using the simplest tools, levers and wedges, built a platform made of railway sleepers, which raised the hull, without removing the ship from the wagon, to a height of $2.4 \mathrm{~m}$. Thanks to this, she was able to roll over the arches of the spans. The road stage was not so easy. On soggy roads, the trailer slipped off the road three times and the entire transport project took up to 30 days. And this time, the lightest, flat-bottomed ship was being transported. This was not a good prognosis for the planned transfer of patrol boats waiting off the Island of Mozambique ${ }^{12}$.

9 Cann, Brown Water, 142.

10 Brázia, Paulo Jorge Martins da, A Marinha Mercante entre 1945-1985. As Grandes Armadoras (Lisboa: Universade de Lisboa, 2010), 154.

11 Cann, Brown Water, 143.

12 Ibidem, 144. 
On 8 October, Marte and Mercúrio were joined by Régulus. The vessel was delivered by the freighter Rovuma (a cargo ship built in 1947 and having a capacity of $9,270)^{13}$. Being the smallest, the last of the ships to arrive was to be the first to set off. By that time, the Portuguese had rented in South Africa two heavy M20 Diamond Model 980 ballast tractors with M9 low-bed trailers (the truck and the trailer together formed the M19 Tank Transporter system) $)^{14}$ and two Leyland 880 FFT tractors. On 19 November, the loading of the ships onto railway wagons began in Lambo ${ }^{15}$. The fact that such security measures were deemed necessary proves the level of threat posed at that time, even several hundred kilometres from the border with Tanzania. The route to Nampula, about $180 \mathrm{~km}$ long, took 9 days. The passage of the ships over the bridge of Malema required the same steps as in the case of LDM 404. The vessels were too wide to pass between the arched supports of the bridge and it became necessary to raise the "cargo" above their level by means of a structure made of railway sleepers. On 30 November, the squad reached Nova Feixo (now Cuamba) and on 1 November it arrived in Catur ${ }^{16}$. However, there was another delay there. In Catur, there were neither tractors with trailers nor the infantry company from the 1891st rifle battalion, assigned to protect them. Eventually, they set off on 2 December. Meanwhile, it started to rain on the night of 2-3 December. The route to Villa Cabral was completed smoothly, but the remaining $65 \mathrm{~km}$ proved to be a serious challenge. On 7 December, the convoy approached a section of the road on which there were three primitive bridges built over rifts $^{17}$. The convoy approached the first bridge, over a stream called Rio Machele, whose carrying capacity was assessed in the report sent to the Navy at 100 tons. Both Leyland tractors crossed it without problems. When the Diamond with the trailer on which Marte was mounted entered the bridge, the beams broke under the trailer's front axles. Fortunately, the front part of it rested against the abutment, and the whole combination remained balanced and did not tip over to the side. The structure was rebuilt with the use of wedges and levers. Then Marte was finally back on the road. However, the passage of the second tractor was not risked and a special earth and wooden dike was built for it. Both combination vehicles finally set off in the morning of 8 December. The second bridge spanned the banks of a stream known

13 Brázia, A Marinha Mercante, 224.

14 This equipment was purchased in the United States by the British Purchasing Commission, and it ended up in the Republic of South Africa along with the $6^{\text {th }}$ Armoured Division, which had returned from the Italian front. Laurent, A Marinha, 225.

16 Cann, Brown Water, 145.

17 The road conditions and the difficulties faced have been well described in a film made by a group of Portuguese veterans: Meponda Moçambique II, accessed: 15.01.2020 https://www.youtube.com/ watch?v=4v_s9c7OIS0. 
as Rio Napita. It was in even worse condition than the previous one and it was necessary to reinforce it. The obstacle was overcome and another delay was basically irrelevant. There were $2 \mathrm{~km}$ to the next bridge, and the road to it was reinforced with steel plates supplied from Meponda. The stream was crossed without problems ${ }^{18}$. A few kilometres to the shore of the lake, however, another serious accident occurred. As the naval carpenter Carlos Águas Trindade recalls:

An observer in an off-road vehicle reported another hole and the driver of the first tractor needed to brake sharply. The rear wheels began to slip and slid to the marshy shoulder (...). Standing with a wedge in my hand, I wondered what to do. During this time, the wheels were sinking and the entire trailer was tilting. I remembered that there were mosquito mounds nearby, and that the hard aggregate obtained from them had been used many times in Africa to harden roads. I went to the back of the column, where an engineering company protected by riflemen was located; they had a bulldozer, transported on a truck, and were accompanied by local workers. Using the machine, it was possible to build a layer of compacted ground, which arrested the increasing tilt of the trailer. After two days of work [in the account written many years later, there is an evident discrepancy between the dates - author's note ] the trailer was pulled back onto the road ${ }^{19}$.

Compared to the obstacles that had been overcome before, launching the boats seemed trivial. There was a long slipway in Meponda, onto which the tractors carefully manoeuvred their trailers backwards and the boats smoothly slid out of their cradles ${ }^{20}$.

In the course of another operation in May 1966 (Operação Atum-2), four more landing boats (LDM 408, LDP 107, LPD 203 and LPD 204) were successfully transported to Niassa. The following year, during the Operação Ruaz carried out between 5 July and 23 August 1967, the forces on Lake Niassa were strengthened with Saturno and Urano patrol boats, as well as the LDM 407 landing boat ${ }^{21}$. The Lake Niassa Squadron (Esquadrilha de Launchas do Lago Niassa, ELLN) reached its maximum force, counting at that time, together with the auxiliary crafts and boats, 14 vessels ${ }^{22}$.

18 Cann, Brown Water, 145.

19 Operação "Atum".

20 Ibidem.

21 Lauret, A Marinha de Guerra, 224.

22 Moçambique, LFP «Saturno» - P 1136, accessed: 15.01.2020, https://reservanaval.blogspot.com/2018 /05/mocambique-lfp-saturno-p-1136.html. 
Table 1. The build-up of Portuguese naval forces on Lake Niassa

\begin{tabular}{|c|c|c|}
\hline Vessel & Arrival date & Remarks \\
\hline Mina & late 1957 & a civil passenger river boat adapted to carry out hydrographic activities \\
\hline Castor (P 580) & December 1963 & $\begin{array}{l}\text { Handed over to Malawi in August 1968, renamed John Chilembwe (also } \\
\text { known as Jobo Milembwe) }\end{array}$ \\
\hline Antares (P 360) & November 1964 & \multirow{4}{*}{ Handed over to Mozambique in 1975} \\
\hline LDM 404 & November 1965 & \\
\hline Marte (P 1134) & December 1965 & \\
\hline Mercúrio (P 1135) & December 1965 & \\
\hline Régulus (P 369) & November 1965 & Handed over to Malawi in March 1969, renamed Chibisa \\
\hline $\mathrm{LP} 1^{*}$ & early 1966 & \multirow{10}{*}{ Handed over to Mozambique in 1975} \\
\hline $\operatorname{LP} 2^{*}$ & early 1966 & \\
\hline LDM 408 & May 1966 & \\
\hline LDM 405 & May 1966 & \\
\hline LDP 107 & May 1966 & \\
\hline LDP 203 & May 1966 & \\
\hline LDP 204 & May 1966 & \\
\hline LDM 407 & August 1967 & \\
\hline Urano (P 1137) & August 1967 & \\
\hline Saturno (P 1136) & August 1967 & \\
\hline
\end{tabular}

* built in Metangula, specification unknown

Source: Author's own elaboration based on: John P. Cann, Brown Waters of Africa. Portuguese Riverine Warfare 1961-1974 (Solihull: Helion \& Company Limited 2016), 148-149; Jane's Fighting Ships 1971-1972, London: McGraw-Hill Inc., 1972), pp. 276-277, 325.

\section{BASE FACILITIES}

As the number of the ships operating on Lake Niassa increased, it became necessary to expand the accompanying facilities. The Portuguese built their main base in Metangula (the name Vila Augusto Cardoso was also used ${ }^{23}$ ), and a manoeuvring base in Cobué. The first one was situated on a peninsula that cut into the waters of the

23 The name commemorates - and has survived to this day - the Portuguese navy officer Augusto de Melo Pinto Cardoso (1859-1930). He came to Mozambique at the age of 25. Under the leadership of the outstanding explorer Alexander de Serpa Pinto, he was mapping the northern part of the colony, from the coast of the Indian Ocean towards Lake Niassa, which was one of the stratagems in the Portuguese-British game. Then he was governor of Lourenço Marques, and then of the province of 
lake for about $2 \mathrm{~km}$. At the peninsula's end, a small ("lake") lighthouse was erected as a navigation sign. A 1,000 m long runway was located along the western shore. Dornier Do 27 and Cessna planes landed there, mainly carrying out medical evacuation tasks. There was a convenient anchorage on the eastern side of the peninsula. At the base of the peninsula, there was a small settlement established in $1900^{24}$. The base provided favourable conditions for the projection of forces in the lake area, but was poorly connected with main supply lines. This, in turn, translated into permanent shortages in supplies, including food. As one of the naval special forces officers stationed there, Lieutenant Raúl Patrício Leitão, recalls: "What could be more important than diversifying our basic menu with fresh vegetables and eggs from a few dozen hens kept next to the workshops" 25 . Another veteran wrote:

being still hungry, I went to a vendor to get eggs. In the canteen I bought my favourite Nocal beer, made an "advocaat" drink and drank it, because I knew it was a "strengthening drug" with high caloric and nutritional value ${ }^{26}$.

In August 1967, at Vaila Auguste Cardoso were stationed four Júpiter-class patrol boats (Marte, Mercúrio, Urano, Saturno), four larger and three small landing craft, as well as two squads of naval special forces ${ }^{27}$. Protection was provided by a company of marines (Compahnia de Fuzileros) and a company of riflemen (Compahnia de Cacaçadores) from the ground forces. In addition, 3-4 locally acquired runabouts were maintained. The base had a mechanical workshop and a radio station. The base perimeter was fortified. It was protected by barbed wire entanglements, machine gun positions and at least two $20 \mathrm{~mm}$ Oerlikon cannons set on land bases ${ }^{28}$.

Cobué is situated $63 \mathrm{~km}$ by air and about $100 \mathrm{~km}$ by road (it takes more than 3 hours to cover it even today) north of Metangula. The town is situated in a shallow gulf curved to the east, facing the Malawi-owned islands of Licoma $(4.3 \mathrm{~km}$ from the coast) and Chisumulo (17 km from the coast). The settlement grew around a mission founded by Italian priests (which could boast a church and a school), but in the first

Inhambane. After the overthrowing of the monarchy in 1910, he symbolically broke his sword and resigned. Later he worked in maritime and customs administration.

Currently, it has about 14,000 residents.

John P. Cann, The Fuzileiros. Portugese Marines in Africa 1961-1974 (Solihull: Helion \& Company Limited 2016), 53.

26 A Ração De Combate, accessed: 26.02.2020, http://contosdaguerracolonial.blogspot.com/2009/11/racao-de-combate.html.

Base Naval de Metangula-Fuzileiros, Reserva Naval, LDM e LDP, accessed: 15.01.2020, https://reservanaval.blogspot.com/search/label/CF\%202.

Farol de Mentangula, accessed: 15.01.2020, http://metangula1.rssing.com/chan-6313448/all_p1.html. 
phase of the war it was abandoned by the population ${ }^{29}$. The abandoned buildings were taken over by the Portuguese, who deployed a platoon of marines and a squad of special forces there. Usually, three small landing craft were kept there. In military terms, the facility was highly exposed to threats, as it was located only about $65 \mathrm{~km}$ from the border with Tanzania.

\section{TASKS AND THEIR FULFILMENT}

In operational terms, the presence of Portuguese forces on the lake was aimed at cutting the infiltration routes used by FRELIMO and demonstrating a strong presence on the lake and in the coastal region. In practice, this task consisted in patrolling $280 \mathrm{~km}$ of the shore to detect guerrilla boats sneaking south along the shores ${ }^{30}$. A permanent guard line was also maintained, crossing the lake at the height of Metangula, which was to stop the influx of partisans to the Tetè province (distance from Kasankha Bay up to $35-40 \mathrm{~km}$ ). However, both tasks proved extremely difficult to carry out. The Portuguese forces lacked vessels and men, and on the west shore, the situation was further complicated by the need to respect the sovereignty of Malawi's waters. In practice, the authorities of this country did not protest against the operation of Portuguese ships in their own waters, but the political constraint related to this issue formally existed.

The patrol activities were, therefore, the main part of the Portuguese naval operations in Lake Niassa. Such tasks were usually carried out by a group consisting of a patrol boat and a landing craft with a platoon of special forces on board. A patrol normally lasted five days. During its course, coastal channels were penetrated and landing groups were deployed at least several times each day; they made contact with local residents in order to both demonstrate presence and collect information. This was extremely important as the guerrilla modus operandi assumed avoiding contact with the Portuguese forces. FRELIMO treated the lake region primarily as a zone of penetration to the south, not another area of confrontation. When detecting the presence of the enemy, boats with activists made for the shore, where they were carefully camouflaged while the combatants sought shelter on land. Maintaining contacts with local residents meant that the Portuguese were quite effective in obtaining news about newly-arrived strangers, because the local population already knew that they demanded various benefits, especially fresh food. On the barren shore, robbing a small community of their supplies could push it dangerously close to the brink of survival. Therefore, out of the

29 Cann, The Fuzileiros, 54.

30 The distance between the water-land boundary at the Mozambique-Tanzania border and the border with Malawi is $212 \mathrm{~km}$. 
two possible solutions, they opted for cooperation with the Portuguese and not with the "liberators" 31 .

The Portuguese navy then developed a specific tactical procedure. In the initial phase of operations, usually on the first night, the patrol boat was anchored or drifted about 1000-2000 $\mathrm{m}$ from the shore and carried out observations with a radar station (Jupiter ships were equipped, for example, with the Decca 330 navigation radar). After the discovery of a boat or a group of boats, manoeuvres aimed at identification were initiated $^{32}$. The ability to conduct radar observation was a major advantage in this case. Another option was to deploy the marines ashore in a place suitable for a temporary base. After disembarking the landing craft or pontoons, the marines would conduct patrols and organise ambushes. During that time, both boats moved further away to a distance that made it impossible to spot them from the shore. In this way, the location of the marines was not revealed, and at the same time, the vessels were kept in adequate proximity to approach the shore and provide gunfire support if necessary. The Portuguese forces preferred to transmit the emergency call signal with visual means (rocket flares), as there were not enough portable radio stations, and, what is more, they often refused to work in difficult climatic conditions. A typical patrol lasted five days, after which soldiers and sailors were given three days to rest, inspect and conduct maintenance of weaponry and equipment ${ }^{33}$. These were extremely tedious, arduous, and both mentally and physically exhausting operations. The enemy was engaged only sporadically, which increased the frustration of the soldiers. The guerrillas were relatively well versed in the course of the shoreline and began to lay mines in places convenient for landing ${ }^{34}$. In order to increase the effectiveness of the operations, the Portuguese experimented with the use of detection dogs, generally to a good result ${ }^{35}$.

31 The relationship between the local population and the partisans, on the one hand, and the Portuguese administration and the army, on the other, is discussed in: Resenha Histórico-Militar das Campanhas de África, 6. ${ }^{\circ}$ Volume, Aspectos da Actividade Operacional, Tomo III, Moçambique, Livro II (Lisboa: Estado-Maior do Exército, Comissão para o Estudo das Campanhas de África (1961-1974), 2012), 97-100.

32 Cann, The Fuzileiros, 54.

33 Ibidem, 54-55.

34 Ibidem.

35 Cães de Guerra no Corpo de fuzileiros, accessed: 17.01.2020, https://barcoavista.blogspot.com/2010/10/ caes-de-guerra-no-corpo-de-fuzileiros.html. 


\section{TACTICAL CASE STUDY}

An example of fulfilment of patrol tasks may be the operations carried out at the end of March 1967. A sub-subunit of 25 marines (with one $60 \mathrm{~mm}$ mortar) was then deployed from a landing craft about $23 \mathrm{~km}$ north of Cobué. The disembarkation was carried out before sunrise. The partisans were then intensively infiltrating the border zone, bearing a relatively small risk, as the topography of the terrain made it relatively easy to detect the enemy approaching by land. The marines, being recently deployed at the lake, could therefore have the advantage of surprise. After disembarking, the soldiers maintained silence and avoided paths and routes, as they suspected them to have been mined. However, this decreased the pace of the march - only three kilometres were covered in an hour. With the dawn, the Portuguese organised an ambush, taking positions on a hill that dominated the area. Two teenage shepherds were captured who revealed that they had sneaked out to fish from a FRELIMO camp, where they had ended up due to "conscription" conducted by the organisation. The camp itself was supposedly located about $7 \mathrm{~km}$ away. According to the testimonies of the prisoners, it was divided into two zones, one was occupied by the combatants while the other provided quarters to local residents, who needed to cater for the "combat component" and had been mostly "mobilised" just like the captured shepherds. The entire camp was protected by a sparse minefield, but well-worn paths led through it. The marines' commander assumed that no more than a dozen militants were stationed in the camp, and thus he had a numerical advantage that allowed him to successfully engage the enemy. So he gave the order to march. It took the marines two hours to travel the area covered with dense vegetation. Then it was time for a short break and deployment to initial positions. Before that happened, the commander instructed the soldiers and non-commissioned officers what their tasks were. Such precautions were necessary because the terrain did not allow command by visual means, and the Portuguese did not have other means of communication (the sub-subunit only had an HF radio station for communication with the command). The plan was simple: go across the minefield in a column formation using the visible path, form a line in the perimeter of the camp and attack to eliminate the enemy in a direct firefight conducted at the shortest possible distance. On the other side of the minefield, there was to be a mortar squad (a gunner and an ammunition man, the second ammunition soldier was included as a rifleman in the assault group), a radio operator and a paramedic, the latter two being tasked with supporting their colleagues using regular G-3 rifles). Of the 27 soldiers, 23 participated in the attack. It took the Portuguese five minutes to cross the minefield and deploy. The partisans felt very confident. No sentries were stationed or they were insufficiently vigilant, as the marines remained undetected, although while marching they themselves could observe the garrison force through the bushes, being occupied 
with their daily, routine morning activities ${ }^{36}$. The wall of dense vegetation ended about 30 metres from the first huts that made up the camp. The Portuguese stepped out into the open as if they were ghosts of the jungle and commenced intense, precise fire from a short distance. The fight was short as the FRELIMO combatants made no effort to organise themselves and rushed to flee. The Portuguese did not give chase. A search of the battlefield revealed that the marines had eliminated (killed or injured) $60 \mathrm{op}$ ponents at the cost of one wounded. About 40 weapons were acquired. At sunset, the entire squad boarded the landing craft again and returned to Cabue $\dot{e}^{37}$.

The aforementioned operation can be considered typical. It well illustrates the capabilities of small, autonomous groups of selected elite soldiers using the advantage provided by landing craft. On the other hand, it demonstrates the weakness of the Portuguese reconnaissance, which made the results of the marines' operations dependent on a proverbial stroke of luck. It is also impossible to ignore the extreme simplification, if not to say crudeness of Portuguese tactics (a phenomenon also observable in other theatres of African wars), and a particular arrogance resulting from the feeling of superiority over the opponent. Therefore, the goal was to shorten the distance as quickly as possible, which often meant - as in the case of the episode described above resigning from the detailed reconnaissance, hoping that this would be compensated by individual training, firepower and determination. This approach was so far successful but was not devoid of a minimal margin for error.

\section{COOPERATION WITH MALAWI}

The Portuguese "lake" flotilla was also an instrument of politics. One of the tasks carried out unofficially and covertly was the training by commandos of the irregular militia from Malawi, i.e. the paramilitary party organisation founded by President Hastings Banda and called Young Pioneers (also known as "green shirts") ${ }^{38}$. Malawi also had no

36 An extremely vivid account of the above-described operation also outlining its much wider context is contained in the memoirs of the commander of the marines' sub-subunit. Raúl Patrício Leitão, O Quarto da Alva (Lisboa: Âncora Editora 2012), 114-137; Raúl Patrício Leitão, Putos da Minha Rua (Lisboa: Âncora Editora 2014), 96-110.

37 Cann, The Fuzileiros, 147.

38 What was important from the Portuguese point of view was the fact that this formation was used to patrol rural areas and, as a result, clashed with FRELIMO fighters marching south. Even ignoring the primary internal role of the pioneers as a structure serving to uphold Banda's power, it should be noted that the Malawi armed forces were completely unable to cope with the infiltration, if only due to the inadequacy of its size for the country's area (approximately $118,000 \mathrm{~km}^{2}$ ). In 1967, 2,000 soldiers served in the Malawian Defence Force. They were mostly veterans of the 1st Battalion, King's African Rifles (locally enlisted British formation). An operational battalion was stationed in the Cobbe barracks in the capital city of Zomba. A significant weakness in Malawi's efforts 
vessel, so its claims to control the waters of the "African sea" were completely abstract. To strengthen relations with Malawi, the Portuguese decided to hand over two patrol boats to their neighbour. In August 1968, the ceremony of taking over Castor took place, and it was renamed John Chilembwe under the new ensign (the name Jobo Milembwe also appears). In March 1969, Castor was joined by Régulus. This boat, in turn, was renamed Chibisa. In the same year, Malawi acquired a $9.1 \mathrm{~m}$ long Spear-type patrol boat from the British company Fairey Marine ${ }^{39}$. At that time, Malawi's sovereignty over the "lake forces" was purely nominal. Most of the crews were Portuguese; for example Castor, before her handover, was assigned an officer and two non-commissioned officers from Mercúrio, who remained on board after the ensign had changed (their salaries were then paid by Malawi). It was a similar case with Régulus. Portuguese support was not limited to personnel. The boats were still serviced and repaired in Metangula, and their daily operation was possible owing to the supply of Portuguese fuel, transported by landing craft across the lake to Monkey Bay (Lusumbwe, southern shore, about $250 \mathrm{~km}$ south of Metangula) where the Malawian Defence Force were attempting to establish a base. The Malawi staff were trained both on the boats under the supervision of the Portuguese and in the unofficial "maritime school" organised in Metangula (most of the students came from the Young Pioneers) ${ }^{40}$.

\section{CONCLUSIONS}

From 1964 to 1974, the Lake Niassa region was the scene of systematic, low-intensity operations by the Portuguese Navy. With the use of a dozen or so light vessels and 1-2 sub-subunits of special forces, whose bases were protected by two companies of marines, a permanent advantage was maintained in a very large water reservoir and over $200 \mathrm{~km}$ of the adjacent coastal belt. This state of affairs continued until the end of the war in 1974. In the early 1970s, the Portuguese forces inflicted such serious losses on the partisans that the leadership of FRELIMO, in practice, abandoned the infiltration route across the lake and along its eastern shore. However, this success had little impact on the end result of the confrontation in Mozambique. When crossing the lake became too risky, a much longer (about $800 \mathrm{~km}$ ) but safer route through Zambia was used. The

was the fact that government forces did not have any vessel at their disposal. The Portuguese operated without any obstacles in their neighbour's waters, but for political and prestige-related reasons, this situation needed to change. Richard Carver, Where Silence Rules: The Suppression of Dissent in Malawi. An Africa Watch Report. October 1990 (New York: Human Rights Watch), 16-27; Young Pioneers (Malawi Congress Party) (Malawi), accessed: 22.06.2020, https://militias-guidebook.com/pgag/72/. 
situation was further worsened by the change of the political line pursued by Malawian President. Hastings Banda, being a seasoned politician, recognised that the chances of the eventual success of the Portuguese were slim and decided to improve his relations with other African countries supporting FRELIMO, especially Tanzania and Zambia. The most important part of this change was allowing the guerrillas to travel through Malawi. This enabled FRELIMO to infiltrate the Mozambique province of Tetè both from the north and the east and then extend its operations south of the River Zambezi. The war entered a new phase. Control of Lake Niassa undoubtedly allowed the Portuguese to prolong it, but it could not prevent the final defeat.

\section{BIBLIOGRAPHY}

A Ração De Combate. Accessed 26.02.2020. http://contosdaguerracolonial.blogspot. com/2009/11/racao-de-combate.html.

Base Naval de Metangula-Fuzileiros, Reserva Naval, LDM e LDP. Accessed 15.01.2020. https://reservanaval.blogspot.com/search/label/CF\%202.

Brázia, Paulo Jorge Martins da. A Marinha Mercante entre 1945-1985. As Grandes Armadoras. Lisboa: Universade de Lisboa, 2010.

Cães de Guerra no Corpo de fuzileiros. Accessed 17.01.2020. https://barcoavista.blogspot. com/2010/10/caes-de-guerra-no-corpo-de-fuzileiros.html.

Cann, John P. Brown Waters of Africa. Portuguese Riverine Warfare 1961-1974. Solihull: Helion \& Company Limited, 2016.

Cann, John P. The Fuzileiros. Portugese Marines in Africa 1961-1974. Solihull: Helion \& Company Limited, 2016.

Carver, Richard. Where Silence Rules: The Suppression of Dissent in Malawi. An Africa Watch Report. October 1990. New York: Human Rights Watch, 1990.

Hamblin, Paul F. Bootsma, Harwey A. Hecky, Robert E. „Surface Meteorological Observations over Lake Malawi/Nyasa". Journal of Great Lakes Research 29 (2003), Supplement 2: 19-33.

Jane's Fighting Ships 1971-1972. London: McGraw-Hill Inc., 1972.

Jane's Fighting Ships 1980-1981. London: London: McGraw-Hill Inc., 1972.

Lauret, Pedro. A Marinha de Guerra Portuguesa. Do fim da II Gueraa Mundial ao 25 Abril de 1974. Vila do Conde: Verso da História, 2015.

Leitão, Raúl Patrício. O Quarto da Alva. Lisboa: Âncora Editora, 2012.

Leitão, Raúl Patrício. Putos da Minha Rua. Lisboa: Âncora Editora, 2014.

Meponda Moçambique II. Accessed 15.01.2020. https://www.youtube.com/watch?v=4v_ s9c7OIS0. 
Moçambique, LFP «Saturno» - P 1136. Accessed 15.01.2020. https://reservanaval.blogspot. com/2018/05/mocambique-lfp-saturno-p-1136.html.

Operação “Atum”. Transporte de Lanchas da Marinha do Lumbo a Meponda. Accessed 13.01.2020. https://niassa1558.blogspot.com/2019/02/operacao-atum-transporte-delanchas-da.html.

Resenha Histórico-Militar das Campanhas de África, 6. Volume, Aspectos da Actividade Operacional, Tomo III, Moçambique, Livro II. Lisboa: Estado-Maior do Exército, Comissão para o Estudo das Campanhas de África (1961-1974), 2012.

Sofala. Accessed 13.01.2020. http://alernavios.blogspot.com/2016/07/sofala.html.

Young Pioneers (Malawi Congress Party) (Malawi). Accessed 22.06.2020. https://militiasguidebook.com/pgag/72/.

English version: Radosław Dolecki, Mark Atkinson

\section{SUMMARY}

For a decade, from 1964 to 1974, the Portuguese Navy planned, organised and conducted low-intensity counterguerrilla activities on Lake Niassa (Nyasa, Malawi). It was one of the theatres of confrontation with the anti-colonial liberation movement. The Portuguese maintained a lasting advantage on Lake Niassa. This fact significantly hindered the use of shipping lanes to transfer guerrillas to Southern Mozambique. In operational, tactical and logistical terms, operations on Lake Niassa are an example of the flexibility of the navy and its ability to face a wide variety of challenges. At the same time, the Portuguese demonstrated considerable organisational skills, as well as the ability to improvise effectively and manage in a rational way very limited resources. The article was based on Portuguese documents, studies and reports, as well as studies in English.

\section{DZIAŁANIA PORTUGALSKIEJ MARYNARKI WOJENNEJ NA JEZIORZE NIASA (1967-1974)}

Słowa kluczowe: Mozambik, jezioro Niasa, wojna partyzancka, działania przeciwpartyzanckie, marynarka portugalska

\section{STRESZCZENIE}

Przez dekadę, w latach 1964-1974, portugalska marynarka wojenna planowała, organizowała i prowadziła działania o niskiej intensywności na jeziorze Niasa. Był to jeden z obszarów konfrontacji z antykolonialnym ruchem wyzwoleńczym. Portugalczycy utrzymali trwałą przewagę na Niasa, co w znacznym stopniu utrudniło wykorzystanie szlaków żeglugowych do przerzutu partyzantów na południe. W wymiarze operacyjnym, taktycznym i logistycznym działania na jeziorze Niasa stanowią przykład elastyczności floty i jej zdolności do stawiania czoła bardzo zróżnicowanym wyzwaniom. Portugalczycy wykazali się przy tym znacznymi umiejętnościami organizacyjnymi, połączonymi ze zdolnością do skutecznej improwizacji, a jednocześnie racjonalnością w dysponowaniu bardzo ograniczonymi 
zasobami. Artykuł jest pierwszą w literaturze polskiej próbą zmierzenia się z tytułowym tematem. Powstał na podstawie portugalskich dokumentów, opracowań i relacji, a także opracowań w języku angielskim. 